\title{
Factors affecting the persistence of traditional agricultural landscapes in Slovakia during the collectivization of agriculture
}

\author{
Juraj Lieskovský • Pavol Kenderessy • \\ Jana Špulerová • Tibor Lieskovský • \\ Peter Koleda $\cdot$ Felix Kienast $\cdot$ Urs Gimmi
}

Received: 5 December 2013/Accepted: 26 March 2014/Published online: 5 April 2014

(C) Springer Science+Business Media Dordrecht 2014

\begin{abstract}
Collectivization of agriculture (1950s1970s) was one of the most important periods in landscape development in Slovakia. Traditionally managed agricultural landscapes, that covered more than half of the Slovak territory, were transformed into large-scale fields and only fragments of traditional agricultural landscapes survived. We mapped the remaining traditional agricultural landscapes using aerial photos and historical maps. We then statistically analyzed the various geographical factors and their influence on the transformation process of traditional and collectivized fields, i.e., slope steepness, soil
\end{abstract}

J. Lieskovský (ه)

Institute of Landscape Ecology SAS, Akademická 2, 94901 Nitra, Slovakia

e-mail: juraj.lieskovsky@savba.sk

J. Lieskovský · F. Kienast · U. Gimmi

Swiss Federal Institute for Forest, Snow and Landscape Research WSL, Zürcherstrasse 111, 8903 Birmensdorf, Switzerland

P. Kenderessy · J. Špulerová

Institute of Landscape Ecology SAS, Stefánikova 3,

81499 Bratislava, Slovakia

T. Lieskovský

Department of Theoretical Geodesy, Slovak University of

Technology, Radlinského 11, 81368 Bratislava, Slovakia

P. Koleda

Soil Science and Censervation Research Institute,

Gagarinova 10, 82713 Bratislava, Slovakia fertility, distance from settlements and isolation from regional capital cities. The comparison was performed using classification tree analysis. We constructed a set of decision rules that explain why fields were managed traditionally or collectivized. Our findings show that traditional agricultural fields were more likely to persist on steep terrain, less fertile soils, and on locations that were closer to the settlements, but more isolated from the regional capital cities. Steepness played the most important role: small-scale fields located on steep areas were not accessible to heavy machinery and therefore, frequently survived the collectivization. We show that the selected geographical factors are good explanatory variables for the collectivization of arable fields and orchards. For vineyards and grasslands, however, the explanatory power of the selected geographical factors is lower, and we suspect that other factors, not depicted in the analysis play an important role.

Keywords Land-use change Classification tree analysis · Driving forces · Post-socialist countries $\cdot$ Resilience $\cdot$ Cultural landscape

\section{Introduction}

Over the millennia, human intervention in natural ecosystems have created a wide variety of agricultural landscapes that have emerged and disappeared in 
Europe. Many landscapes have undergone multiple transformations: dynamic periods followed periods of relative stability. We can find legacies of historical landscapes such as open fields, e.g., coltura promiscua and bocage in Western Europe (Deckers et al. 2005), remnants of medieval field patterns called pluzina in the Czech Republic (Molnárová 2008; Sklenicka et al. 2009), traditional common lands in United Kingdom (Jones 2013; Newton 2013), terraced landscapes in Mediterranean regions (Agnoletti et al. 2011; Barbera and Cullotta 2012; Bevan et al. 2013) and agrarian mosaic landscapes in Central Europe (Štefunková and Dobrovodská 2009; Babicová and Gerhátová 2011; Baránková et al. 2011; Baran-Zgłobicka and Zgłobicki 2012) and in other continents as well (Palang 2010; Fischer et al. 2012).

The transformation of traditional landscapes started with the social and political revolutions since the eighteenth century, when the necessary technological power became available (Antrop 1997). However, most of the studies on traditional agricultural landscapes refer to landscapes that remained relatively unchanged during the industrialization period after the Second World War (Calvo-Iglesias et al. 2009; Agnoletti et al. 2011; Johann 2013). In Slovakia (Bezák and Mitchley in Press; Izakovičová and Oszlányi 2012; Kanianska et al. 2014) and other post-socialistic countries (Sklenicka et al. 2009; Bell et al. 2009; Palang 2010; Rohring and Gailing 2012; Fischer et al. 2012), a crucial role was played by the collectivization of agriculture.

Collectivization was a politically driven process, based on the socialist idea of common property that should be for the benefit of all working people equally. The aim of the collectivization was to minimize private property and to consolidated all agricultural land to large-scale fields suitable for industrial agriculture. Basically, Central and Eastern European countries followed the Soviet example. However, agricultural land was not completely nationalized in Slovakia as it was in former Soviet Union countries (Swinnen 1999; Palang 2010). Rather, ownership rights were gradually reduced.

Collectivization in Czechoslovakia started in 1949, when president Klement Gotwald declared that "There will be no socialism, if the countryside will not turn to socialism." In the same year, new legislation to establish the Unified Agricultural Cooperatives were defined. The farmers entering the
Cooperative transferred all agricultural and forest land to the cooperative farm. Formally, it was a voluntary decision. In reality, farmers were forced into it by political and economic pressure driven by the government and its bureaucracy. For example, the farmers that did not reach production quotas, were obligated to give land to the agricultural cooperative. Those that refused to give their land to the cooperatives were often marked as "kulaks" (Russian word for exploiters) and were summoned to court. Usually they had the choice to either give their land to a cooperative farm, or to spend several years in prison. Some of the individual stories of the victims of collectivization are documented in The Nation's Memory Institute in Bratislava. Many farmers were forced out of their homeland and started to commute as employees to nearby urban centres that had expanding industry and urbanization. The number of people employed in agriculture decreased from 918,000 in 1948 (60\% of economically active population) to 290,000 in 1989 (12\%) (Bezák and Mitchley in Press).

The main wave of land concentration ended in 1959. According to Demo (2001), an area of 1,789,178 ha (65\% of total agricultural land) was managed by 2,709 cooperatives in 1960. An additional 377,104 ha $(13.7 \%)$ of state agricultural land (nationalized after the Second World War or during the collectivization process), was managed by state farms. Under a new law (No. 49/1959), cooperatives could be further merged to achieve an "optimal" size. As a result, the number of cooperatives dropped from 2,683 to 1,902 in 1970, and the average cooperative size increased. Finally, regulation No. 123/1975 granted the right to agricultural organizations to use private land to ensure agricultural production. Before the end of communism in 1989, the mean size of collective and state farms was 2,667 and 5,186 ha respectively (Mathijs and Noev 2004). The goal of food self-sufficiency was achieved in the 1980s (Cambel 2005).

Collectivization fundamentally changed the overall character of rural areas (Lipsky 1995; Kristiánová and Adamková 2010; Hresko et al. 2010). The socialist ideal of equality and uniformity was applied to the "ideological" uniform landscape (Maandi 2009). There were, however, factors that inhibited a full transformation of the landscape which led to the remnants of the traditional agricultural landscapes discussed in this paper. TAL in Slovakia are defined as 
the remaining mosaic of small-scale arable fields or permanent agricultural cultivations such as grasslands, vineyards and high-trunk orchards or early abandoned plots of low succession degree, which have not been affected by agricultural collectivization (Špulerová et al. 2011). TAL are agricultural ecosystems that are characterized by the following features: (a) the smallscale structure of the plot division is preserved (b) the presence of original forms of anthropogenic relief (balks) (c) unchanged land use during the collectivization of agriculture and (d) the use of some traditional agricultural technologies.

According to data from the Statistical Office of the Slovak Republic, the area of the traditionally managed agricultural landscape before the collectivization was $2,287,000$ ha-more than half of the entire Slovak territory. The current area of traditional agricultural landscapes is about 44,455 ha, which is $<1 \%$ of Slovakia (Špulerová et al. 2011). The purpose of this paper is to identify the main geographic factors and determine their potential role in the transformation or persistence of traditional agricultural landscapes in Slovakia during times of agriculture collectivization. Specifically, our aims were to (1) identify the geographic factors that played a key role in the process of land collectivization (2) compare the geographical factors of the collectivized and noncollectivized fields and (3) find the set of decision rules used for keeping the fields traditionally managed or for collectivizing them.

\section{Methods}

Mapping of traditional agricultural landscapes

The methodology of TAL mapping was published in Dobrovodská et al. (2010) and Śpulerová et al. (2011). The preserved TAL in Slovakia were mapped using a combined method comprising visual interpretation of aerial photos and field surveys in 2009-2011. The visual interpretation was performed using Google Earth aerial pictures taken in 2007. TAL were identified based on the following characteristics: (1) polygons consisting of more than five mosaic fields (2) land use did not change since the time of collectivization of agriculture (pre-collectivization land use was identified from historical topographic maps) (3) polygons are not overgrown by trees-(i.e. $<50 \%$ woody vegetation) and (4) the area of the polygon is larger than $5,000 \mathrm{~m}^{2}$. The combination of characteristics (1)-(4) creates a spatial pattern which clearly distinguishes TAL from surrounding areas (Fig. 1). In a second step, approximately $20 \%$ of the sites were randomly selected from the Natural-settlement nodal regions of Slovakia (Miklós 2002). The selected sites were visited, attributes from the aerial mapping were verified, and additional data were recorded (e.g. the threat factors and vegetation information).

We analyzed four types of agricultural field: arable fields, grasslands, vineyards and orchards. The mapped TAL polygons were assigned to these four types according to the dominant land-cover type within the mosaic. To obtain land-cover information from the time of collectivization, we used historical military topographical maps from 1950 to 1956.

The boundaries of collectivized fields were taken from the current land parcel identification system (LPIS) which is the database of individual agricultural fields that are eligible for Common Agricultural Policy subsidies. The LPIS polygons were interpreted from aerial photos and verified in the field using a similar method as described above for TAL polygons. In this way, the resulting databases are comparable. To filter out those large-scale fields, that have just recently been created and are not a result of agriculture collectivization, we referred to the Corine Land Cover map from 1990 and restricted our analyses to those large-scale fields that were already present in the 1990 s (i.e. the end of socialist era).

Analysis of geographical factors

\section{Slope steepness}

We derived slope steepness from a digital elevation model (DEM) based on contour maps with a scale of 1 : 10,000. To improve the DEM elevation points and elevation, breaklines (ridges, streams) have been used. For the interpolation, the ANUDEM TopoToRaster tool software was used. The resolution of the DEM and the slope raster was $30 \mathrm{~m}$.

\section{Soil fertility}

To analyze soil fertility, we used the national soil database of Bonited Pedo-Ecological Units provided by the Soil Science and Conservation Research 

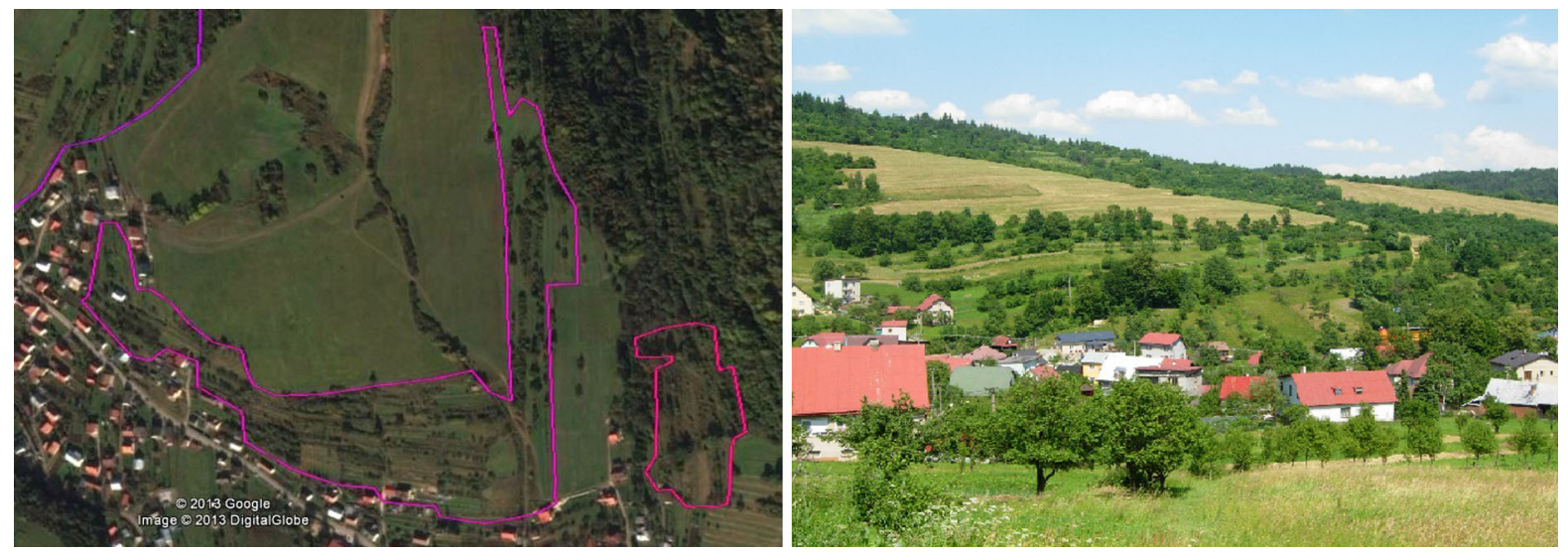

Fig. 1 Traditional agricultural landscape in Ochodnica (North-East Slovakia). Left-TAL polygons based on Google Earth picture interpretation, Right_-picture taken at field research site

Institute in Bratislava. Soil fertility is expressed as a soil production potential (SPP) on a scale ranging from 0 to 100 (0 for non-productive soils, and 100 for the most fertile soils). According to (Džatko 2002) the SPP is a function of soil type (ST), slope steepness and aspect (SA), skeletal content and depth (SD), grain size distribution $(\mathrm{G})$ and climate factor $(\mathrm{K})$ :

$\mathrm{SPP}=\mathrm{K}(\mathrm{ST}+\mathrm{SA}+\mathrm{SD}+\mathrm{G})$

\section{Accessibility}

We evaluated the accessibility as the time (in minutes) a person needs to walk from settlement to closest TAL mosaic. For the analysis, we used the VARCOST module from the IDRISI software. This approach was found to be the most suitable for distance analyses in comparative studies (Danielisová 2008; Horňák 2012). First, we analyzed the effect of topography to walking speed by calculating the friction of the surface, as function of the slope steepness. We then incorporated the effect of different land cover types that could have a barrier effect (buildings, rivers), could retard the walking speed (meadows, fields, forests), or could facilitate the walking (paved roads, paths, bridges, etc.). For the land-cover map, we used the Corine Land Cover layer from 1990 (Feranec et al. 1995). The friction coefficients, expressed by the proportion of the average walking speed without friction and retarded speed by different land-cover types (Table 1), were derived from empirical experience and from published sources (Soule and Goldman 1972; Mezníková 2011).
Table 1 Friction coefficients for analyzed land cover types

\begin{tabular}{lll}
\hline Land cover & $\begin{array}{l}\text { Friction } \\
\text { coefficient }\end{array}$ & Remark \\
\hline $\begin{array}{l}\text { Buildings, fences, } \\
\text { water courses }\end{array}$ & 99 & Barrier effect \\
$\begin{array}{l}\text { Railways } \\
\begin{array}{l}\text { Motorways, pathways, } \\
\text { bridges }\end{array}\end{array}$ & 1 & $\begin{array}{l}\text { Crossable barrier } \\
\text { No friction }\end{array}$ \\
$\begin{array}{l}\text { Meadows } \\
\text { Bare soils }\end{array}$ & 1.28 & $\begin{array}{l}\text { Mezníková (2011) } \\
\text { Soule and Goldman } \\
(1972)\end{array}$ \\
$\begin{array}{l}\text { Forest } \\
\text { Landscape } \\
\text { (background) }\end{array}$ & 1.31 & $\begin{array}{c}\text { Soule and Goldman } \\
(1972)\end{array}$ \\
\hline
\end{tabular}

\section{Isolation}

Isolation was evaluated as the distance in hours by car from the TAL mosaic to the closest regional capital city (Bratislava, Banská Bystrica, Košice). For the analyses, we used the "Cost grow" algorithm, incorporated in the COST module (Eastman 2003) for the IDRISI software. The surface friction was adjusted for the use of motor vehicles (the effect of a road network is higher than the effect of relief topography). We used the map of the current road network, from which we excluded those highways that did not exist at the time of the collectivization. The maximum car speed was limited at $120 \mathrm{~km} / \mathrm{h}$ on existing highways and $60 \mathrm{~km} /$ 
$\mathrm{h}$ on roads. We also incorporated the walking distance from roads to the TAL mosaic for the areas that were not directly accessible by a car.

\section{Statistical analysis of data}

For each polygon, we calculated the average value of geographical factors and compared collectivized (48,849 polygons) versus non-collectivized polygons (2,871 in total) as response variables. To do so, we used a classification tree analysis: a non-parametric, probabilistic machine-learning method that classifies a response variable based on binary splits applied to predictors (Breiman et al. 1984). The splitting rules are defined in order to get the greatest increase in class purity for each node until the nodes reach the defined criteria. In order to terminate the tree's growth and avoid tree over-fitting, we limited the minimum number of polygons in any terminal node to 50 and allowed the next split only if the cross-validation error, expressed by cost-complexity parameter (cp), decreased by the $\mathrm{cp}$ factor of 0.01 . For cross-validation, we used a v-fold method. Observations were split into 10 subsamples, and trees were calculated, without the excluded subsample that was used as a test sample for validation. The average cross validation error was then computed for each split. We used the Gini splitting method for the tree-fitting algorithm (Breiman et al. 1984). Since we were comparing polygons with different sizes, we weighted them with respect to polygon area. Therefore, the classification procedure aimed at minimizing the misclassification area (ratio between the misclassified area and the total classified area) instead of the number of misclassified polygons.

We used the Pearson correlation coefficient to test the co-linearity of the predictors. It was necessary to take the high correlation between the slope and soil fertility $(\mathrm{R}=-0.80)$ into consideration for the interpretation of results and discussion. The analysis was executed with $\mathrm{R}$ statistical software using the rpart package.

\section{Results}

Arable fields

Our analysis suggest that slope obviously was a crucial factor affecting the preservation of traditional arable

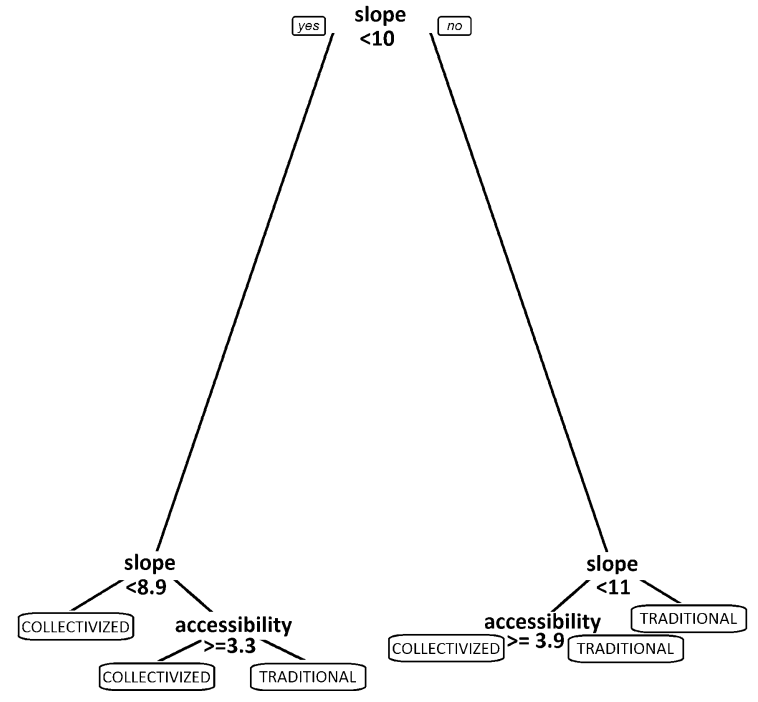

Fig. 2 Classification tree representing the role of selected geographical factors in the process of collectivization of arable land. (The vertical distance between the splits corresponds to the proportion of deviance explained by the splits). Misclassification rates: total 0.003 , collectivized fields 0.0007 , traditional fields 0.173 . Number of samples: collectivized fields 31,467 , traditional fields 1,549

fields (Fig. 2). The split rule shows that flat fields (slopes $<8.9^{\circ}$ ) were collectivized; fields on steep slopes (slopes steeper than $11^{\circ}$ ) remained in small parcels and were not collectivized. It is obvious that for intermediate slopes (split rule: slope between $8.9^{\circ}$ and $11^{\circ}$ ), collectivization or persistence was influenced by accessibility: less accessible fields were more likely to be collectivized, and the fields close to settlements tended to remain for private farming. Because of the high correlation between slope and fertility $(\mathrm{R}=-0.72$ for the arable fields), we are unable to draw definite conclusions regarding the relationship between the slope and collectivization. However, given the fact that steepness limits the use of heavy machinery, we suppose that slope was more important than fertility for determining collectivization in this case.

Grasslands

As highlighted in Fig. 3, high misclassification rates with this land-use type indicate that the selected predictors are probably not the key drivers for transformation or persistence of traditional grasslands. Nevertheless, it seems that accessibility is the most 


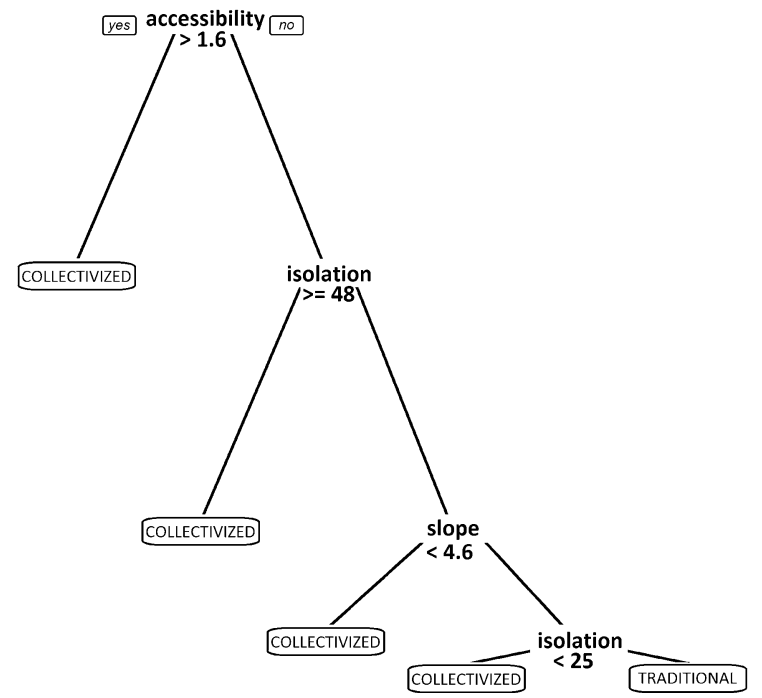

Fig. 3 Classification tree representing the role of selected geographical factors in the process of collectivization of grasslands. (The vertical distance between the splits corresponds to the proportion of deviance explained by the splits). Misclassification rates: total 0.040 , collectivized fields 0.006 , traditional fields 0.623 . Number of samples: collectivized fields 16,307, traditional fields 493

important factor: less accessible fields were more likely to be collectivized. The role of isolation is unclear. More isolated fields tend to be collectivized, but with steeper slopes, the influence of isolation is the opposite. Flat grassland patches however, appear to be more frequently collectivized than steep ones.

\section{Vineyards}

Even though the first split is based on isolation of the patches, the proportion of deviance explained by slope on the second split is the most important. Traditional vineyards tend to remain in isolated areas with higher slopes and low fertility, or in very isolated, steep areas. However, high misclassification rates indicate that there are also other factors that affected the preservation of traditional vineyards (Fig. 4).

\section{Orchards}

The most important factor is fertility, which depends partly on steepness. Therefore, we speculate that the role of slope is underestimated in that case. Traditional orchards tend to remain in less fertile areas (with higher slopes), or in areas with better accessibility.

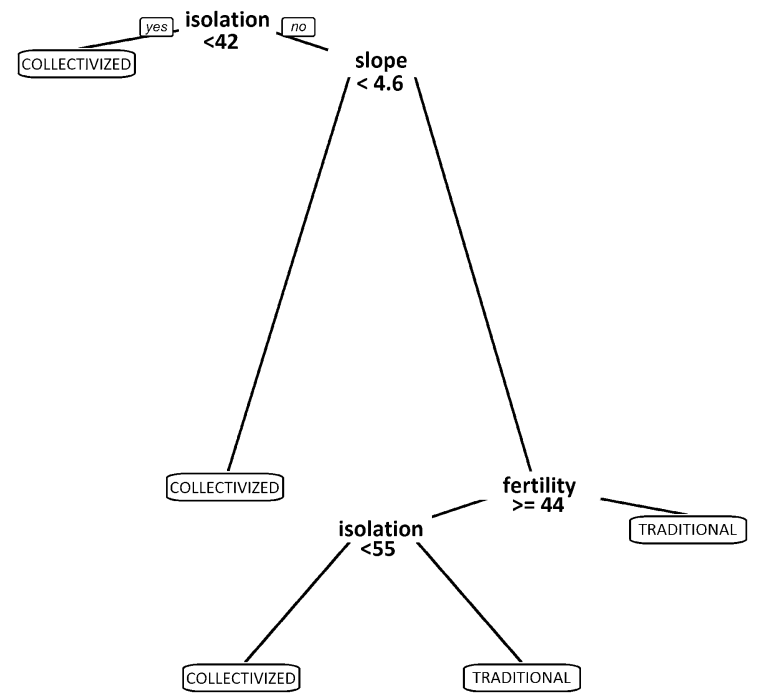

Fig. 4 Classification tree representing the role of selected geographical factors in the process of collectivization of vineyards. (The vertical distance between the splits corresponds to the proportion of deviance explained by the splits). Misclassification rates: total 0.253 , collectivized fields 0.210 , traditional fields 0.327 . Number of samples: collectivized fields 818, traditional fields 243

Low misclassification rates show, that these variables explain the preservation of traditional orchards sufficiently (Fig. 5).

\section{Discussion and conclusions}

This paper is a timely contribution to the understanding of the processes that determined transformation or persistence of TAL during the collectivization period in socialist Slovakia. Both collectivization and persistence of TAL were driven by political decisions. The majority of agricultural land was concentrated and collectivized. On the other hand, fragments of TAL survived due to regulation num. 69/1949, that allowed members of the cooperative farms to keep 0.5 ha of agricultural land (and an additional 0.5 ha of pastureland in submountain areas) for family farming.

From our findings, we have strong evidence that collectivization particularly affected those land patches that had the potential to increase production. Traditional agricultural landscapes remained on steep slopes, less fertile soils, and on sites close to the settlements, but that were more isolated from regional capital cities. Steepness is the major discriminant 


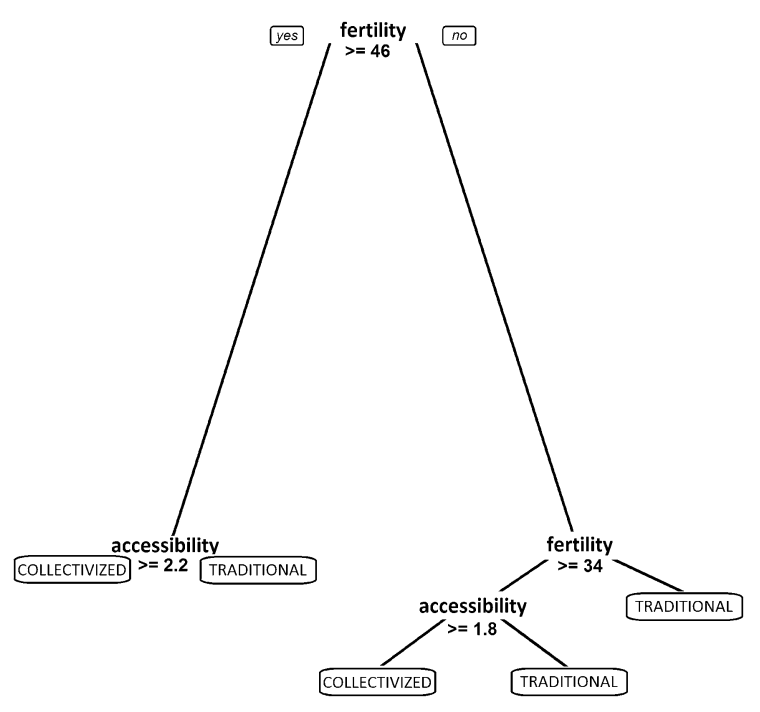

Fig. 5 Classification tree representing the role of selected geographical factors in the process of collectivization of orchards. (The distance between the split corresponding to the proportion of deviance explained by the splits). Misclassification rates: total 0.061 , collectivized fields 0.087 , traditional fields 0.048. Number of samples: collectivized fields 255, traditional fields 586

variable for collectivization of arable fields and vineyards. The small-scale fields that were located on steep areas were not accessible for heavy machinery, and therefore remained untouched by collectivization. This is in agreement with the overarching hypothesis that landscape changes in a given region are linked to their geomorphological characteristics (Bürgi et al. 2004) and with observations of the persistence of traditional agricultural landscapes in many European regions (Sklenicka et al. 2009; Agnoletti et al. 2011; Solymosi 2011).

Since soil fertility is statistically highly correlated with slope steepness ( $\mathrm{R}=-0.80$ for all polygons), it is difficult to determine pure relationship between those two factors and TAL persistence. Nevertheless, we analyzed soil fertility separately from steepness even if those two variables are highly correlated. This co-linearity could lead to underestimating the role of fertility in those cases where the splits were based on slope and vice versa. Our result identified soil fertility as an important driver. According to land consolidation rules, private parcels that were barriers for collective farming were taken away from owners and exchanged with parcels with the same or $20 \%$ lower fertility. Practically speaking, those private farmers that did not join the cooperative farm, often got the least fertile soils in the cadastral area (Demo 2001). Our results are in agreement with other studies which also relate soil fertility to TAL persistence (Sklenicka et al. 2009) and to landscape change in general (Domon and Bouchard 2007; Baumann et al. 2011; Prishchepov et al. 2013).

Accessibility (distance from settlements) played an ambiguous role in TAL persistence. While the land that was left to cooperative members for family farming was usually located close to settlements, private farmers who did not join the cooperative farm, were re-located to remote areas during the land rearrangement process (Demo 2001). Since the number of private farmers was gradually reduced, most of the traditionally managed fields observed today are located closer to settlements. This ambiguous role of accessibility described above is responsible for the low explanatory power of this variable. Accessibility is the main discriminant in the case of grassland only, but the overall importance of geographical factors is low. This is in contrast to studies in Belgium where distance from settlements was found to be important for the development of TAL (Deckers et al. 2005). We, however, recognize the fact that accessibility is an important factor in the process of agricultural abandonment in post-socialist countries (Prishchepov et al. 2013; Müller et al. 2013).

According to Solymosi (2011), isolation is the main factor that determines persistence of traditional cultural landscape hotspots in Europe. It could be any form of isolation due to specific socio-economical, cultural, political conditions or land property conditions (Vos and Meekes 1999). Physical constraints in upland and remote areas prevent the modernization of agriculture (Plieninger et al. 2006). Modern development occurs faster near transportation nodes (Antrop 2005), along roads, railroad tracks and close to local centres (Solymosi 2011). In the Slovak case, even though more isolated fields were more likely to be preserved, isolation did not play such an important role as proposed by the authors above. In Western Europe, the transformation of traditional agricultural landscapes was driven by the ongoing adaptation of the agricultural sector to the global economy (Bignal and McCracken 2000; Strijker 2005; Widgren 2012), where isolation played a substantial role. Conversely, in the majority of Central and Eastern European countries, collectivization of agriculture was a 
political decision, made with no regards to economic profitability of large-scale farming in isolated areas (Rohring and Gailing 2012).

Methodologically, we experienced a few problems that are common in landscape-historical research, and are mainly related to incomplete data availability. Regarding the difficulty in capturing the full sample of TAL that survived the collectivization of agriculture, it must be acknowledged that the greater part of the land was collectivized until 1960, the collectivization effectively ended in the middle of seventies and communism regime ended in 1989. Since, we mapped the remaining TAL in 2010 and 2011. This implies, that the TAL that were abandoned or transferred to another land-use type after the end of communism were consequently omitted from our data. Indeed, agricultural land abandonment was a widespread phenomenon in Slovakia (Munteanu et al. 2014; Gerard et al. 2010) and other post-socialistic countries during the transition to market-oriented economy (Kuemmerle et al. 2008; Baumann et al. 2011; Alcantara et al. 2012; Prishchepov et al. 2013; Griffiths et al. 2013). For the analysis of collectivized fields, we used the layer of agricultural fields mapped in 2010. This layer contains some new fields that originated after the end of communism. To filter-out those fields, we used the Corine Land Cover layer from 1990. Since the Corine Land Cover was mapped with a coarser scale (minimum mapping unit was $25 \mathrm{ha}$ ), not all new large-scale fields were recognized and filtered out. In turn, some isolated large-scale fields that originated during the collectivization period were not recognized in the coarse Corine Land Cover layer and were filtered out. A similar problem occurred with the map featuring current settlements and the road network (except highways) which was used to calculate accessibility and isolation for the time of collectivization. Since the current road network (except highways) is literally based on the old road system, and the distribution of settlements has not changed substantially, we believe that the use of the new map would not significantly influence the isolation calculation.

We analyzed only four geographical factors, which we hypothesized to be the most significant for TAL persistence in a process of agriculture collectivization. It appears that the four predictor variables explain the persistence of traditional orchards and arable fields sufficiently, since the misclassification rates (ratio of misclassified area to the total classified area) were low. In the case of grasslands, the total misclassification rates were low as well, but this was mainly caused by an unequal number of collectivized and non-collectivized fields. Only $38 \%$ of traditional grasslands were classified correctly. Since the management of collectivized and non-collectivized grasslands is relatively similar and is not as intensive as in the case of arable land, we may, therefore, conclude that geographic conditions did not play an important role in collectivization. In the case of vineyards, the role of analyzed geographical factors was influential, but there were other factors that may have played significant roles as well. These include economic factors (Strijker 2005; Solymosi 2011; Widgren 2012), changes in population density and age structure (Bruns et al. 2000; Petrovič 2006; Elbakidze and Angelstam 2007; Rescia et al. 2012), historical land use (Deckers et al. 2005; Sklenicka et al. 2009), cultural differences (Solymosi 2011), education level and willingness for innovation (Bignal and McCracken 2000; Pinto-Correia and Breman 2008), as well as other factors, or causes and conditions of landscape evolution (Zarina 2010), that played a role on a local scale.

Even though the study of landscape persistence is desirable (Bürgi et al. 2004), there are only few studies that have analyzed the persistence of traditional agricultural landscapes. According to a review by Solymosi (2011), there are three main preconditions determining the existence of traditional cultural landscape hotspots: (1) isolation (in geographic, economic, infrastructural, political and cultural terms) (2) a geographical setting which is difficult for agriculture and (3) ethnic or social differences from the national mainstream. In case of Slovakia, we found the geographical settings for agriculture (slope and fertility) to be more important than isolation. While we did not analyze ethnic or social differences, it is possible they played a role, especially in the case of vineyards, since wine making has a long tradition and is part of local culture and identity in particular localities.

In this study, we have analyzed the persistence of TAL at the time of collectivization. After the transition to an open-market economy, landscape dynamics have changed completely and additional factors now play important roles. As TAL are vanishing rapidly, there is a great need to find a sustainable approach to improve their ability to survive the pressure of globalization. More studies regarding TAL dynamics and resilience, 
such as Hresko et al. (2010), Lieskovský et al. (2013), Mojses and Petrovič (2013), will help to design the policy rules to keep these landscapes preserved and vital.

Acknowledgments This paper is the result of project funding from the Slovak Research and Development Agency (No. APVV-0866-12, "Evaluation of ecosystem functions and services of the cultural landscape"). The cooperation between the Institute of Landscape Ecology of Slovak Academy of Sciences and the Swiss Federal Institute for Forest, Snow and Landscape Research WSL was supported by Scientific Exchange Programme NMS-CH. The authors are sincerely grateful to three anonymous reviewers for their comments and suggestions.

\section{References}

Agnoletti M, Cargnello G, Gardin L et al (2011) Traditional landscape and rural development: comparative study in three terraced areas in northern, central and southern Italy to evaluate the efficacy of GAEC standard 4.4 of cross compliance. Ital J Agron 6:121-139

Alcantara C, Kuemmerle T, Prishchepov AV, Radeloff VC (2012) Mapping abandoned agriculture with multi-temporal MODIS satellite data. Remote Sens Environ 124:334-347. doi:10.1016/j.rse.2012.05.019

Antrop M (1997) The concept of traditional landscapes as a base for landscape evaluation and planning. The example of Flanders Region. Landsc Urban Plan 38:105-117

Antrop M (2005) Why landscapes of the past are important for the future. Landsc Urban Plan 70:21-34. doi:10.1016/j. landurbplan.2003.10.002

Babicová D, Gerhátová K (2011) Mosaic of historical structures of agricultural landscape in the Juhoslovenská kotlina basin. In: Dobrovodská M, Špulerová J, Štefunková D (eds) Research and management of the historical landscape. Institute of Landscape Ecology, Slovak Academy of Sciences, Bratislava, pp 87-95

Baránková Z, Dobrovodská M, Štefunková D et al (2011) Participation of local people on identifying the landscape values and future development in historical agricultural landscapes. Ekologia 30:216-228. doi:10.4149/ekol_ 2011_02_216

Baran-Zgłobicka B, Zgłobicki W (2012) Mosaic landscapes of SE Poland: should we preserve them? Agrofor Syst 85:351-365. doi:10.1007/s10457-011-9436-x

Barbera G, Cullotta S (2012) An inventory approach to the assessment of main traditional landscapes in sicily (Central Mediterranean Basin). Landsc Res 37:539-569. doi:10. 1080/01426397.2011.607925

Baumann M, Kuemmerle T, Elbakidze M et al (2011) Patterns and drivers of post-socialist farmland abandonment in Western Ukraine. Land Use Policy 28:552-562. doi:10. 1016/j.landusepol.2010.11.003

Bell S, Nikodemus O, Penēze Z, Krūze I (2009) Management of cultural landscapes: what does this mean in the former
Soviet Union? A case study from Latvia. Landsc Res 34:425-455. doi:10.1080/01426390903020328

Bevan A, Conolly J, Colledge S et al (2013) The long-term ecology of agricultural terraces and enclosed fields from Antikythera, Greece. Hum Ecol 41:255-272. doi:10.1007/ s10745-012-9552-x

Bezák P, Mitchley J (in Press) Drivers of change in mountain farming in Slovakia: from socialist collectivisation to the common agricultural policy. Reg Environ Change 1-14. doi:10.1007/s10113-013-0580-x

Bignal EM, McCracken DI (2000) The nature conservation value of European traditional farming systems. Environ Rev 8:149-171

Breiman L, Friedman J, Olshen RA, Stone CJ (1984) Classification and regression trees. Wadsworth, Monterey

Bruns D, Ipsen D, Bohnet I (2000) Landscape dynamics in Germany. Landsc Uurban Plan 47:143-158

Bürgi M, Hersperger AM, Schneeberger N (2004) Driving forces of landscape change-current and new directions. Landscape Ecol 19:857-868

Calvo-Iglesias MS, Fra-Paleo U, Diaz-Varela RA (2009) Changes in farming system and population as drivers of land cover and landscape dynamics: the case of enclosed and semi-openfield systems in Northern Galicia (Spain). Landsc Urban Plann 90:168-177. doi:10.1016/j.landurb plan.2008.10.025

Cambel S (2005) Pätdesiate roky na slovenskej dedine. Najťǎ̌šie roky kolektivizácie. Universum, Prešov

Danielisová A (2008) Praktické problémy spojené s modelovaním pohybu pravěkou kulturní krajinou. In: Macháček J (ed) Počítačová podpora v archeologii 2, Ústav archeologie a muzeologie. Masarykova univerzita, Brno, pp 110-119

Deckers B, Kerselaers E, Gulinck H et al (2005) Long-term spatio-temporal dynamics of a hedgerow network landscape in Flanders, Belgium. Environ Conserv 32:20-29

Demo M (2001) History of agriculture in Slovakia. Slovak Agricultural University, Nitra, p 662

Dobrovodská M, Špulerová J, Štefunková D, Halabuk A (2010) Research and maintenance of biodiversity in historical structures in the agricultural landscape of Slovakia. In: Barančoková M, Krajčí J, Kollár J, Belčáková I (eds) Landscape ecology—methods, applications and interdisciplinary approach. Institute of Landscape Ecology, Slovak Academy of Sciences, Bratislava, pp 131-140

Domon G, Bouchard A (2007) The landscape history of Godmanchester (Quebec, Canada): two centuries of shifting relationships between anthropic and biophysical factors. Landscape Ecol 22:1201-1214. doi:10.1007/s10980-0079100-z

Džatko M (2002) Hodnotenie produkčného potenciálu poľnohospodárskych pôd a pôdno-ekologických regiónov Slovenska. VÚPOP, Bratislava

Eastman JR (2003) IDRISI Kilimanjaro: guide to GIS and image processing. Clark Labs, Clark University, Worcester

Elbakidze M, Angelstam P (2007) Implementing sustainable forest management in Ukraine's Carpathian Mountains: the role of traditional village systems. For Ecol Manage 249:28-38. doi:10.1016/j.foreco.2007.04.003

Feranec J, Oťahel J, Šúri M (1995) The corine land cover project in Slovakia. Ekológia (Bratislava) 29:49-52 
Fischer J, Hartel T, Kuemmerle T (2012) Conservation policy in traditional farming landscapes. Conserv Lett 5:167-175. doi:10.1111/j.1755-263X.2012.00227.x

Gerard F, Petit S, Smith G et al (2010) Land cover change in Europe between 1950 and 2000 determined employing aerial photography. Prog Phys Geogr 34:183-205. doi:10. 1177/0309133309360141

Griffiths P, Müller D, Kuemmerle T, Hostert P (2013) Agricultural land change in the Carpathian ecoregion after the breakdown of socialism and expansion of the European Union. Environ Res Lett 8:045024. doi:10.1088/17489326/8/4/045024

Horňák M (2012) Analýza priechodnosti krajinou v prostredí GIS (Diplomová práca). Slovak Technical University, Bratislava

Hresko J, Kanasova D, Petrovic F (2010) Landscape archetypes as the elements of Slovak historical landscape structure. Ekologia 29:158-173. doi:10.4149/ekol_2010_02_158

Izakovičová Z, Oszlányi J (2012) The landscape of Slovakia, its nature and transformations. In: Elmar C (ed) In lost landscapes : reflections from Central European Border Regions. Regional Development Agency Mura, Murska Sobota, pp 115-131

Johann E (2013) The history of utilization and management of commons and consequences of current social change in the Alpine Region of Austria. In: Rotherham ID (ed) Cultural severance and the environment the ending of traditional and customary practice on commons and landscapes managed in common. Springer, Dordrecht, pp 133-146

Jones M (2013) Traditional uses, destruction, survival and restoration of common land: a south yorkshire perspective. In: Rotherham ID (ed) Cultural severance and the environment the ending of traditional and customary practice on commons and landscapes managed in common. Springer, Dordrecht, pp 275-287

Kanianska R, Kizeková M, Nováček J, Zeman M (2014) Landuse and land-cover changes in rural areas during different political systems: a case study of Slovakia from 1782 to 2006. Land Use Policy 36:554-566. doi:10.1016/j. landusepol.2013.09.018

Kristiánová K, Adamková J (2010) Slovak agricultural landscape-transition responses. A Z ITU J Fac Archit 7: 121-132

Kuemmerle T, Hostert P, Radeloff VC et al (2008) Cross-border comparison of post-socialist farmland abandonment in the Carpathians. Ecosystems 11:614-628. doi:10.1007/ s10021-008-9146-z

Lieskovský J, Kanka R, Bezák P et al (2013) Driving forces behind vineyard abandonment in Slovakia following the move to a market-oriented economy. Land Use Policy 32:356-365. doi:10.1016/j.landusepol.2012.11.010

Lipsky Z (1995) The changing face of the Czech rural landscape. Landsc Urban Plan 31:39-45. doi:10.1016/01692046(94)01034-6

Maandi P (2009) The silent articulation of private land rights in Soviet Estonia: a geographical perspective. Geoforum 40:454-464. doi:10.1016/j.geoforum.2009.03.003

Mathijs E, Noev N (2004) Subsistence farming in Central and Eastern Europe: empirical evidence from Albania, Bulgaria, Hungary, and Romania. East Euro Econ 42:72-89
Mezníková L (2011) Analýza nejkratších cest na mapách pro orientační běh (Diplomová práca). České vysoké učení technické v Praze. Vypočetní a informační centrum, Praha

Miklós L (2002) Natural—settlement nodal regions. Atlas krajiny SR. MŽP, Bratislava, pp 206-207

Mojses M, Petrovič F (2013) Land use changes of historical structures in the agricultural landscape at the local levelHriňová case study. Ekologia 32:1-12

Molnárová K (2008) Long-term dynamics of the structural attributes of hedgerow networks in the Czech Republicthree case studies in areas with preserved medieval field patterns. J Landsc Stud 1:113-127

Müller D, Leitão PJ, Sikor T (2013) Comparing the determinants of cropland abandonment in Albania and Romania using boosted regression trees. Agric Syst 117:66-77. doi:10.1016/j.agsy.2012.12.010

Munteanu C, Kuemmerle T, Boltiziar M et al (2014) Forest and agricultural land change in the Carpathian region - a metaanalysis of longterm patterns and drivers of change. Land Use Policy 38:685-697. doi:10.1016/j.landusepol.2014.01. 012

Newton AC (2013) Biodiversity conservation and the traditional management of common land: the case of the new forest. In: Rotherham ID (ed) Cultural severance and the environment the ending of traditional and customary practice on commons and landscapes managed in common. Springer, Dordrecht, pp 353-370

Palang H (2010) Time boundaries and landscape change: collective farms 1947-1994. Euro Countrys 2:169-181

Petrovič F (2006) Changes of the landscape with dispersed settlement. Ekológia (Bratislava) 25:201-211

Pinto-Correia T, Breman B (2008) Understanding marginalisation in the periphery of Europe: a multidimensional process. In: Brouwer F, Rheenen $\mathrm{T}$, Van Dhillion SS, Elgersma AM (eds) Sustainable land management: strategies to cope with the marginalisation of agriculture. Edward Elgar Publishing Ltd, Cheltenham, pp 11-40

Plieninger T, Höchtl F, Spek T (2006) Traditional land-use and nature conservation in European rural landscapes. Environ Sci Policy 9:317-321. doi:10.1016/j.envsci.2006.03.001

Prishchepov AV, Müller D, Dubinin M et al (2013) Determinants of agricultural land abandonment in post-Soviet European Russia. Land Use Policy 30:873-884. doi:10. 1016/j.landusepol.2012.06.011

Rescia A, Pérez-Corona ME, Arribas-Ureňa P, Dover JW (2012) Cultural landscapes as complex adaptive systems: the cases of northern Spain and northern Argentina. In: Plieninger T, Bieling C (eds) Resilience and the cultural landscape: understanding and managing change in human-shaped environments. Cambridge University Press, New York, pp 126-145

Rohring A, Gailing L (2012) Linking path dependency and resilience for the analysis of landscape development. In: Plieninger T, Bieling C (eds) Resilience and the cultural landscape: understanding and managing change in humanshaped environments. Cambridge University Press, New York, pp 146-163

Sklenicka P, Molnarova K, Brabec E et al (2009) Remnants of medieval field patterns in the Czech Republic: analysis of driving forces behind their disappearance with special 
attention to the role of hedgerows. Agric Ecosyst Environ 129:465-473. doi:10.1016/j.agee.2008.10.026

Solymosi K (2011) Indicators for the identification of cultural landscape hotspots in Europe. Landsc Res 36:3-18. doi:10. 1080/01426397.2010.530647

Soule RG, Goldman RF (1972) Terrain coefficients for energy cost prediction. J Appl Physiol 32:706-708

Špulerová J, Dobrovodská M, Lieskovský J et al (2011) Inventory and classification of historical structures of the agricultural landscape in Slovakia. Ekologia 30:157-170. doi:10.4149/ekol_2011_02_157

Štefunková D, Dobrovodská M (2009) Preserved European cultural heritage in agrarian landscape of Slovakia. Tájökológiai Lapok 7:283-290

Strijker D (2005) Marginal lands in Europe-causes of decline. Basic Appl Ecol 6:99-106. doi:10.1016/j.baae.2005.01.001
Swinnen JF (1999) The political economy of land reform choices in Central and Eastern Europe. Econ Transit 7:637-664

Vos W, Meekes H (1999) Trends in European cultural landscape development: perspectives for a sustainable future. Landscape Urban Plan 46:3-14

Widgren M (2012) Resilience thinking versus political ecology: understanding the dynamics of small-scale, labour-intensive farming landscapes. In: Plieninger T, Bieling C (eds) Resilience and the cultural landscape: understanding and managing change in human-shaped environments. Cambridge University Press, New York, pp 95-110

Zarina A (2010) Path dependency and landscape biographies in Latgale, Latvia: a comparative analysis. Euro Countrys 2:151-168. doi:10.2478/v10091-010-0011-7 